\title{
A Soil-Borne Mn(II)-Oxidizing Bacterium of Providencia sp. Exploits a Strategy of Superoxide Production Coupled To Hydrogen Peroxide Consumption To Generate Mn Oxides
}

\section{Sha Chen}

Hunan University of Technology

\section{Zhexu Ding}

Hunan University of Technology

\section{Jinyuan Chen}

Hunan University of Technology

Jun Luo

Hunan University of Technology

Xiaofang Ruan

Hunan University of Technology

Zongpei Li

Hunan University of Technology

\section{Fengfeng Liao}

Hunan University of Technology

Jing $\mathrm{He}$

Hunan University of Technology

Ding Li ( $\sim$ liding@hut.edu.cn )

Hunan University of Technology https://orcid.org/0000-0001-6721-6680

\section{Research Article}

Keywords: Providencia sp., Mn(II) oxidation, reactive oxygen species, phenylacetic acid catabolism

Posted Date: October 19th, 2021

DOI: https://doi.org/10.21203/rs.3.rs-972208/v1

License: @) (1) This work is licensed under a Creative Commons Attribution 4.0 International License. Read Full License

Version of Record: A version of this preprint was published at Archives of Microbiology on February 12th, 2022. See the published version at https://doi.org/10.1007/s00203-022-02771-7. 


\section{Abstract}

Bacterial non-enzymatic Mn(II) oxidation involving reactive oxygen species (ROS) (i.e. indirect oxidation), initially discovered from a marine alpha-proteobacterium, is believed to be of importance in controlling biogeochemical cycles. For soil-borne bacteria, however, evidence of indirect Mn(II) oxidation remains unclear. In this study, the indirect Mn(II) oxidation was evidenced in a soil-borne bacterium, Providencia sp. LLDRA6. First, with and without $50 \mathrm{mM}$ of Mn(II) exposure for LLDRA6, 300 differentially expressed genes were found to be linked to $\mathrm{Mn}$ (II) exposure via transcriptome sequencing. Among them, an operon, responsible for phenylacetic acid catabolism, was sharply upregulated in transcription, drawing us a special attention since its transcriptional upregulation has recently shown to be important for withstanding ROS. Next, a fluorometric probe, 2',7'-Dichlorofluorescin diacetate (DCFDA), was used to qualitatively detect ROS from cells, showing a distinct increase in fluorescence intensities of ROS during Mn(II) exposure. Further, concentrations of superoxide and hydrogen peroxide from cells were detected respectively with and without $\mathrm{Mn}$ (II) exposure, exhibiting that when $\mathrm{Mn}$ (II) oxidation occurred, superoxide concentration significantly increased but hydrogen peroxide concentration significantly decreased. Particularly, superoxide produced by LLDRA6 was proven to be the oxidant for $\mathrm{Mn}$ (II) in the formation of $\mathrm{Mn}$ oxides. Finally, we predicted links between phenylacetic acid metabolism pathway and ROS during Mn(II) exposure, proposing that the excessive ROS, generated in response to $\mathrm{Mn}$ (II) exposure, transcriptionally activate phenylacetic acid catabolism presumably by increasing concentrations of highly reactive oxepins.

\section{Introduction}

The oxidation of soluble Mn(II) to insoluble Mn(III/IV) minerals plays a critical role in global biogeochemical cycles, greatly affecting the fate and transport of trace elements, the cycling of carbon-based nutrients, and the activity of microbial metabolisms (Learman et al. 2011a). Over 30 different types of Mn (oxyhydr) oxides (hereon Mn oxides), with layered or tunnel structures, occur in a wide variety of environmental settings from oceans to soils (Hens et al. 2018). These ubiquitous minerals exhibit high binding affinity to metal ions because of their large surface-to-volume porous structure, and are often used as one of the strongest metal scavengers in the environment (Butterfield et al. 2016). Moreover, due to the presence of unstable, highly reactive $\mathrm{Mn}(\mathrm{III})$ in these minerals, Mn oxides are powerful oxidants, capable of degrading a number of recalcitrant organic matters (Learman et al. 2011a). Apart from strong sorptive and oxidative capacity, Mn oxides are often involved in microbial metabolisms. In the absence of oxygen, $\mathrm{Mn}$ oxides (e.g., $\mathrm{MnO}_{2}$ ) can be terminal electron acceptors, supporting the respiration and growth of certain anaerobic Mn-reductive bacteria (Henkel et al. 2019).

Despite being thermodynamically favorable for the oxidation of $\mathrm{Mn}$ (II) by $\mathrm{O}_{2}$ in the environment, most naturally occurring $\mathrm{Mn}$ oxides are likely attributed to bacterial $\mathrm{Mn}$ (II) oxidation, because $\mathrm{Mn}$ (II)-oxidizing bacteria play a dominant role in accelerating the rate of $\mathrm{Mn}$ biomineralization in nature, which is several orders of magnitude faster than abiotic pathways (Tebo et al. 2004; Morgan, 2005; Butterfield et al. 2016). Generally, two protein families perform direct $\mathrm{Mn}$ (II) oxidation coupled to $\mathrm{O}_{2}$ reduction: the multicopper oxidases (MCOs), and the peroxidase cyclooxygenases (Lingappa et al. 2019).

Previous studies have shown that MCOs and their gene clusters have been identified in a diverse array of bacteria, such as Bacillus sp. PL-12 (mnx) (Dick et al. 2008a), Leptothrix discophora SS-1 (mof) (Corstjens et al. 1997), Pseudomonas putida GB-1 ( $m c o A$ and $m n x G$ ) (Geszvain et al. 2013), Bacillus sp. SG-1 ( $m n x$ ) (van Waasbergen et al. 1996; Francis et al. 2002), and Pedomicrobium sp. ACM 3607 (mox) (Larsen et al. 1999; Ridge et al. 2007). Usually, these MCOs share low homology except for their copper binding motifs (Ridge et al. 2007), which contain a unique $\mathrm{Cu}$ (II) center (type I Cu) and a trinuclear Cu cluster composed of one type II and two type III Cu atoms (Kataoka et al. 2007). Although a variety of gene clusters of MCOs have been identified, isolation of the responsible enzymes is still a challenge (Butterfield et al. 2013; Soldatova et al. 2017a). Among these enzymes, MnxG, has now been successfully isolated from Bacillus sp. PL-12, together with accessory proteins MnxE and MnxF as a multimeric complex (known as Mnx), by expressing four contiguous genes as part of an operon in E.coli (Butterfield et al. 2013). Recently, the mechanism of Mn(II) oxidation by protein Mnx has been shown to exploit the polynuclear chemistry of $\mathrm{Mn}$, in the oxidation states II, III, IV, to nucleate $\mathrm{MnO}_{2}$ nanoparticles (Soldatova et al. 2017a; Soldatova et al. 2017b; Soldatova et al. 2019). 
In addition to MCOs, another class of bacterial proteins responsible for direct $\mathrm{Mn}$ (II) oxidation is described as peroxidase cyclooxygenase. Strictly speaking, these proteins show a certain degree of sequence homology to animal heme peroxidases (AHPs), which belong to peroxidase cyclooxygenase superfamily of peroxidases (Anderson et al. 2009; Nakama et al. 2014). Like MCOs, they are believed to be outer membrane proteins, with no direct involvement in energy conservation (Lingappa et al. 2019). Also, these enzymes adopt a way of single electron transfer to form an intermediate of $\mathrm{Mn}$ (III), which is further oxidized to Mn(IV) oxides via disproportionation, or by another MCOs-type enzyme (Schlosser and Höfer, 2002; Nakama et al. 2014). Now, these AHPs-like enzymes, consisted of animal heme peroxidase domains and hemolysin-type $\mathrm{Ca}$ (II) binding domains, have been named Mn(II)-oxidizing peroxidases (MopA), as found in Aurantimonas manganoxydans SI85-9A1 (Anderson et al. 2009; Dick et al. 2008b), Erythrobactersp. SD-21 (Anderson et al. 2009; Nakama et al. 2014) and Pseudomonas putida GB-1 (Geszvain et al. 2016). In A. manganoxydans SI85-9A1 and P. putida GB-1, MopA has two animal heme peroxidase domains and two $\mathrm{Ca}$ (II) binding domains. Comparatively, in Erythrobactersp. SD-21, MopA has only one animal heme peroxidase domain and one $\mathrm{Ca}$ (II) binding domain (Anderson et al. 2009; Nakama et al. 2014). Therefore, mechanisms of direct Mn(II) oxidation by MopA may be different in these bacterial species. For instance, hydrogen peroxide stimulated the activity of MopA identified in A. manganoxydans SI85-9A1, but had no positive effect on MopA in Erythrobacter sp. SD-21, which required NAD ${ }^{+}$rather than hydrogen peroxide for Mn(II) oxidation (Anderson et al. 2009; Nakama et al. 2014; Johnson and Tebo, 2008; Medina et al. 2018).

Apart from the two above-mentioned ways of direct Mn(II) oxidation by bacteria, nowadays, a third pathway of Mn(II) oxidation by bacteria, i.e. indirect oxidation, attracts more and more attention, after widespread discovery of production of extracellular superoxide by heterotrophic bacteria (Diaz et al. 2013). An example of indirect Mn(II) oxidation is well described in Roseobactersp. AzwK-3b, a representative within the Roseobacter clade that comprises the ca. $20 \%$ of marine bacterial communities (Learman et al. 2011b; Learman and Hansel, 2014; Andeer et al. 2015; Hansel et al. 2019). In this case, superoxide $\left(\mathrm{O}_{2}^{-}\right)$, one of reactive oxygen species (ROS), probably generated by extracellular AHPs-like enzymes, dehydrogenases and NADH-oxidoreductases, plays a central role in Mn(II) oxidation. However, a high level of superoxide produced by bacteria cannot ensure their generation of Mn oxides (Diaz et al. 2013; Learman and Hansel, 2014). Theoretically, the removal of hydrogen peroxide is necessary to pull the equilibrium (reaction 1) towards accumulation of Mn(III), thus minimizing the back reaction of $\mathrm{Mn}$ (III) reduction (Lingappa et al. 2019; Andeer et al. 2015). So, both superoxide production and hydrogen peroxide consumption are required for ROS-dependent generation of Mn oxides (Andeer et al. 2015).

$$
\mathrm{Mn}(\mathrm{II})+\mathrm{O}_{2}^{-}+2 \mathrm{H}^{+} \leftrightarrow \mathrm{MnO}_{2}^{+}+2 \mathrm{H}^{+} \leftrightarrow \mathrm{Mn}(\mathrm{III})+\mathrm{H}_{2} \mathrm{O}_{2}(1)
$$

To date, it is generally accepted that the mechanism of bacterial direct-Mn(II) oxidation is better understood than that of indirect-Mn(II) oxidation. Evidence for bacterial indirect $\mathrm{Mn}$ (II) oxidation is mostly obtained from the marine bacterium Roseobactersp. AzwK-3b. Thus, discovery of new bacterial species of indirect Mn(II) oxidation from different environments will benefit to deepen the understanding of the link between Mn cycling, ROS and health of microbial populations (Andeer et al. 2015; Hansel et al. 2019), because indirect Mn(II) oxidation may involve numerous bacteria from oceans to soils, significantly contributing to global biogeochemical cycles (Diaz et al. 2013). Recently, we identified a Mn(II)-oxidizing bacterium from soils, Providencia sp. LLDRA6, a powerful scavenger for heavy metals from soils because of its high production of Mn oxides ( $\mathrm{Li}$ et al. 2020). Here, we explored the mechanism of Mn oxides generation by Providencia sp. LLDRA6, using a combination of genome sequencing, transcriptomic analyses and chemical activity assays. Collectively, these data demonstrated that this bacterium was a ROS-dependent producer of Mn oxides.

\section{Materials And Methods}

\subsection{Strain and incubation conditions}

Providencia sp. LLDRA6 is a Gram-negative bacterium (China Center for Type Culture Collection: M2018876), originally isolated from soil samples near a smelting factory $\left(113^{\circ} 09^{\prime} 11.48 " \mathrm{E}\right.$ and $\left.27^{\circ} 87^{\prime} 07.411^{\prime \prime} \mathrm{N}\right)$ at Zhuzhou, Hunan Province, China, exhibiting high tolerance and strong oxidation ability for Mn(II) (Li et al. 2020). The strain LLDRA6 was incubated in the dark 
by using the sterile Luria-Bertani (LB) liquid medium $\left(5 \mathrm{~g} \cdot \mathrm{L}^{-1}\right.$ of yeast extract powder, $10 \mathrm{~g} \cdot \mathrm{L}^{-1}$ of peptone, $5 \mathrm{~g} \cdot \mathrm{L}^{-1}$ of sodium chloride, and $\mathrm{pH}=7$ ) in a rotary shaker with $180 \mathrm{rpm}$ at $35^{\circ} \mathrm{C}$. The incubation conditions of darkness, $180 \mathrm{rpm}$ and $35^{\circ} \mathrm{C}$ for cell growth were maintained in all experiments unless otherwise noted. The chemical reagents prepared for LB media were purchased from Sinopharm Chemical Reagent Co., Ltd, China.

\subsection{Genome summary of Providencia sp. LLDRA6}

Data of genomic sequencing for LLDRA6 by PacBio RS II and Illumina HiSeq 4000 platforms at the Beijing Genomics Institute (BGI, Shenzhen, China) are deposited at the Genbank with accession number of CP067099. The clean reads of genome sequencing are deposited in the NCBI Sequence Read Archive under BioProject PRJNA724814. The genome sequence of 4.34 Mb was obtained with no gaps by assembling 1,131 Mb Illumina data (260 coverage) with 1,497 Mb PacBio data (344 coverage), consisting of a circular chromosome with a $\mathrm{G}+\mathrm{C}$ content of $40.18 \%$. A total of 3,956 genes were found, of which 3,818 genes $(96.51 \%)$ were functionally annotated via cluster of orthologous groups of proteins (COG). The principal features for the genome of strain LLDRA6 are shown in Fig. S1 and Table S1.

\subsection{Determination of the optimum time of cell incubation and $\mathrm{Mn}$ (II) exposure for $\mathrm{Mn}$ (III) accumulation by strain LLDRA6 via trapping assays of $\mathrm{Mn}(\mathrm{III})$-intermediate by the ligand pyrophosphate}

The optimum time parameters of incubation and $\mathrm{Mn}$ (II) exposure for cells to accumulate $\mathrm{Mn}$ (III) were determined via trapping assays of Mn(III)-intermediate by the ligand pyrophosphate (PP) as previously described (Thi et al. 2018). Briefly, a single colony of strain LLDRA6 obtained from the LB agar plate was incubated for $12 \mathrm{~h}$ in the LB liquid medium. Then, $100 \mu \mathrm{L}$ of cell suspension (ca. 1.0 1.5 $\times 10^{7} \mathrm{CFU} / \mathrm{mL}$ ) were inoculated into a fresh $50 \mathrm{~mL}$ of LB liquid medium (at a volume ratio of $0.2 \%$ ), incubating for $4 \mathrm{~h}, 8 \mathrm{~h}, 12 \mathrm{~h}$, and $24 \mathrm{~h}$, respectively. Subsequently, stock solutions of $1 \mathrm{M}$ of $\mathrm{MnCl}_{2}$ and $200 \mathrm{mM}$ of $\mathrm{Na}_{4} \mathrm{P}_{2} \mathrm{O}_{7}$ (sodium pyrophosphate, S108847, Aladdin) were simultaneously added into cell suspensions, both reaching a final concentration of $0.5 \mathrm{mM}$, with cells being constantly incubated for different times ranging from 0 to $36 \mathrm{~h}$, i.e. time for cells to be exposed with $\mathrm{Mn}(\mathrm{II})$. After that, the adsorption spectra of $\mathrm{Mn}$ (III)-PP complexes at different $\mathrm{Mn}(\mathrm{II})$ exposure times were monitored by performing a ultraviolet-visible (UV-vis) spectrophotometer (TU-1810, Pgeneral, China) in a range of 200-600 nm.

\subsection{Experimental design for transcriptome sequencing of strain LLDRA6 with and without $\mathrm{Mn}(\mathrm{II})$ exposure}

In order to obtain information on differentially expressed genes (DEGs) between the short-term and the long-term exposure of $\mathrm{Mn}(\mathrm{II})$, four types of cDNA libraries for transcriptome sequencing were constructed from strain LLDRA6 according to the methods as described by Zhang et al. (2018), including LLDRA6 with a short-term exposure of $50 \mathrm{mM}$ of Mn(II), LLDRA6 with a long-term exposure of $50 \mathrm{mM}$ of $\mathrm{Mn}(\mathrm{II})$, and two controls of LLDRA6 with no exposure of $\mathrm{Mn}(\mathrm{II})$ in the corresponding periods, which were denoted as the $\mathrm{Mn}$ (II)-short group, the Mn(II)-long group, the CK-short group, and the CK-long group, respectively. The flowchart of experimental design for transcriptome sequencing was shown in Fig. S2.

Specifically, according to results of the above-mentioned $\mathrm{Mn}$ (III) trapping assays (section 2.3), the optimum incubation time when cells are the most active for $\mathrm{Mn}$ (III) production (denoted as a h, which could be any one among 4, 8, 12, and $24 \mathrm{~h}$ ), and the optimum time for cells to accumulate $\mathrm{Mn}$ (III) (denoted as $b \mathrm{~h}$, which could be any one in the range of 0-36 h), were determined as the time parameters for cell incubation and the long-term $\mathrm{Mn}$ (II) exposure prior to transcriptome sequencing, respectively. For short-term Mn(II) exposure, its time parameter was set as $0.5 \mathrm{~h}$, considering that on the one hand, it is unlikely to generate Mn oxides by Mn(II)-oxidizing bacterium in such a short time. On the other hand, such a short time of Mn(II) exposure would result in a wide range of transcriptional alteration in cells due to stress responses, of which the majority might not really attach to $\mathrm{Mn}$ (II) oxidation and thus could be served as a reference when comparing with transcriptional data obtained from the long-term $\mathrm{Mn}$ (II) exposure. Additionally, the concentration of $50 \mathrm{mM}$ used in $\mathrm{Mn}$ (II) exposure was determined according to the results of our previous study, in which strain LLDRA6 showed the best yield of Mn oxides at 50 $\mathrm{mM}$ of $\mathrm{Mn}(\mathrm{II})$ (Li et al. 2020). 
In detail, a single colony from the LB agar plate was incubated for $12 \mathrm{~h}$ in the LB liquid medium. Subsequently, cell suspension (ca. $1.0 \sim 1.5 \times 10^{7} \mathrm{CFU} / \mathrm{mL}$ ) were inoculated into a fresh LB liquid medium at a volume ratio of $0.2 \%$, incubating for $a \mathrm{~h}$ in advance. After that, the cells were immediately exposed to $50 \mathrm{mM}$ of $\mathrm{Mn}$ (II) by adding the stock solution of $\mathrm{MnCl}_{2}$ to the cell suspension. After $0.5 \mathrm{~h}$ (short-term exposure) or $b \mathrm{~h}$ (long-term exposure) of further incubation, the cells of $\mathrm{Mn}$ (II)-short group or $\mathrm{Mn}$ (II)-long group were harvested by centrifugation for subsequent transcriptome sequencing. Meanwhile, cells incubated with no exposure of $\mathrm{Mn}(\mathrm{II})$ in the corresponding periods (i.e., $a+0.5 \mathrm{~h}$ and $a+b \mathrm{~h}$, respectively) were regarded as controls (i.e., CK-short group and CK-long group, respectively). Each treatment group consisted of three biological replicates.

\subsection{Data analysis of transcriptome sequencing}

Transcriptome sequencing data of twelve cell samples obtained by using an Illumina HiSeq 4000 platform at the Beijing Genomics Institute (BGI, Shenzhen, China), are deposited at Sequence Read Archive in NCBI (BioProject PRJNA690198).

After RNA sequencing (RNA-seq), clean reads of twelve cell samples were mapped to the reference genome (Fig. S1) by the STAR software (Dobin et al. 2013), and then transcript quantification was carried out by the RSEM software (Li and Dewey, 2011). TPM (Transcripts Per Kilobase Million) analysis was used to calculate gene expression levels, and then the edgeR was used to investigate DEGs between different groups as instructed in section 2.4 (Robinson et al. 2010). A two logarithmic foldchange $\left(\log _{2} F C\right)>1$ or $<-1$, and a $p$-value $<0.05$ were used as the criteria to define significant DEGs. Finally, the Kyoto Encyclopedia of Genes and Genomes (KEGG) mapping was used to characterize the metabolic pathways of significant DEGs. The KEGG enrichment analysis was performed using the OmicShare tools (http://www.omicshare.com/tools).

\subsection{Verification of RNA-seq data by quantitative real time-PCR}

To validate the RNA-seq data, a total of 21 genes were selected from DEGs between the Mn(II)-short group and the Mn(II)-long group for qRT-PCR analyses. The primers of these 21 genes for qRT-PCR were listed in Table S2. The 16s rRNA gene (Ranieri et al. 2012) and the gyrA gene (Fan et al. 2012) were used as internal controls (primers were listed in Table S2). For the negative control, $\mathrm{ddH}_{2} \mathrm{O}$ was used as the DNA template in qRT-PCR. The results were analyzed using the $2^{-\triangle \triangle C T}$ method as previously described (Livak and Schmittgen, 2001).

Briefly, total RNA was extracted from the cells of $\mathrm{Mn}$ (II)-short group and $\mathrm{Mn}$ (II)-long group newly incubated as instructed by the

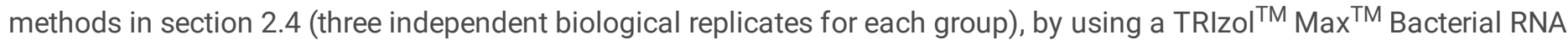
Isolation Kit (16096020, Invitrogen) according to the manufacturer's instructions. Subsequently, the first-strand cDNA of RNA samples was synthesized by reverse transcription using a SuperScript IV First-Strand Synthesis System Kit (18091050, Invitrogen) according to the manufacturer's instructions. For each PCR, $1 \mu \mathrm{L}$ of template cDNA was mixed with $12.5 \mu \mathrm{L}$ of 2×SYBR Green PCR Master Mix (Roche, Basel, Switzerland) and 5 pmoL of each forward and reverse primer in a final reaction volume of $25 \mu \mathrm{L}$. Amplification program was performed as following reaction conditions: $15 \mathrm{~s}$ at $95^{\circ} \mathrm{C}$, followed by $15 \mathrm{~s}$ at a temperature $5^{\circ} \mathrm{C}$ below the primer's true $\mathrm{Tm}$, and $20 \mathrm{~s}$ at $72^{\circ} \mathrm{C}$ for 45 cycles. For each PCR, a thermal denaturing step to generate the dissociation curves was carried out to verify amplification specificity.

\subsection{ROS measurements}

Prior to ROS measurements, cells were incubated in the exactly same manner as done for transcriptome sequencing (section 2.4), including four groups of $\mathrm{Mn}$ (II)-short, CK-short, Mn(II)-long, and CK-long. Of note, the cell density of controls (CK-short and CK-long) was commonly higher than that of Mn groups (Mn(II)-short and Mn(II)-long) owing to the ambient stress from 50 $\mathrm{mM}$ of $\mathrm{Mn}(\mathrm{II})$ ions. So, before tests, the cell density $\left(\mathrm{OD}_{600}\right)$ of controls was adjusted equally to that of $\mathrm{Mn}$ groups by diluting with sterilized liquid medium. In addition, LB liquid medium and dead cells (autoclaved) were used as abiotic controls for ROS measurements (For a better understanding, the specific treatments for LB liquid medium, dead cells, and living cells before ROS measurements, were straightforwardly illustrated in the legend of Fig. 4).

For qualitative detection of ROS, cells were centrifuged from cell suspension and then resuspended in the same volume of PBS buffer (P1010, Solarbio, China). The Bacterial ROS Assay Kit (HR9066, Beijing Baiaolaibo Science and Technology Co., 
Ltd., China) was used to detect ROS from cells by 2',7'-dichlorofluorescin diacetate (DCFDA), according to the manufacturer's instructions. The fluorescence intensity was measured at Ex/Em 488/526 nm (F-7100 Fluorescence Spectrophotometer, Hitachi, Japan).

The Superoxide Anion Assay Kit (SA-2-G, Suzhou Comin Biotechnology Co., Ltd., China) and Hydrogen Peroxide Assay Kit $\left(\mathrm{H}_{2} \mathrm{O}_{2}-2-\mathrm{Y}\right.$, Suzhou Comin Biotechnology Co., Ltd., China) were used to quantitively detect $\mathrm{O}_{2}^{-}$and $\mathrm{H}_{2} \mathrm{O}_{2}$ from cells, respectively, according to the manufacturer's instructions. Before detection, cells were collected by centrifugation from cell suspensions and then resuspended in buffer solutions as supplied by the kits for subsequent ultrasonication (200 W, working time $10 \mathrm{~s}$, interval time $5 \mathrm{~s}, 30$ cycles) using an ultrasonic homogenizer (JY92-IIN, Scientz, China). So, $\mathrm{O}_{2}^{-}$and $\mathrm{H}_{2} \mathrm{O}_{2}$ detected from cells are supposed to include intracellular ones and the ones that externally attach to the membranes.

\subsection{Statistical analysis}

All statistical analyses were performed with SPSS22.0. Data were subjected to statistical evaluation using analysis of variance (ANOVA) followed by $t$-test, with a significant level of $P<0.05$. All data were means \pm standard deviations (SD) for three independent replicates.

\section{Results And Discussion}

\subsection{The optimum time of cell incubation and $\mathrm{Mn}$ (II) exposure for $\mathrm{Mn}(\mathrm{III})$ accumulation by strain LLDRA6}

The accumulation of unstable $\mathrm{Mn}$ (III)-intermediate is an essential, indispensable step for generation of $\mathrm{Mn}$ (IV) oxides from $\mathrm{Mn}$ (II) ions, also indicative of the occurrence of $\mathrm{Mn}$ (II) oxidation. To determine the effect of cell activity on Mn(III) accumulation, and when $\mathrm{Mn}(\mathrm{III})$ accumulation will occur in the presence of strain LLDRA6, trapping assays of Mn(III)intermediate by the ligand PP were performed on cells with different incubation times and different Mn(II) exposure times.

Figure 1(A, B, C and D) presents the UV-vis adsorption spectra of bacterial suspensions consisted of Mn(II), PP and cells at incubation times of $4 \mathrm{~h}, 8 \mathrm{~h}, 12 \mathrm{~h}$, and $24 \mathrm{~h}$, respectively. As a frequently-used chelating agent, PP has shown to be capable of stabilizing the transient Mn(III)-intermediate, thus forming Mn(III)-PP complexes that are easily detected by UV-vis spectrophotometer (Cui et al. 2008). It can be seen that characteristic peaks of Mn(III)-PP complexes formed under different incubation times all occur at $258 \mathrm{~nm}$, which are similar to that of Mn(III)-PP complexes generated by Pseudomonas putida MnB1 (Thi et al. 2018). As cell incubation time increased from $4 \mathrm{~h}$ to $24 \mathrm{~h}$ (Figure 1A-D), the absorbance intensities at $258 \mathrm{~nm}$ gradually declined, suggesting that before Mn(II) exposure, cells with $4 \mathrm{~h}$ of incubation might be the most active for production of $\mathrm{Mn}$ (III)-intermediate in comparison to cells with longer incubation time. An explanation for this trend could be that at $4 \mathrm{~h}$ of incubation, cells were in the mid-exponential growth phase, and then they entered in the stationary growth phase since the 12th h, as evidenced by $\mathrm{OD}_{600}$ in the previous study (Li et al. 2020).

Furthermore, regardless of cell incubation time, $8 \mathrm{~h}$ of $\mathrm{Mn}$ (II) exposure was the optimum time for cells to accumulate $\mathrm{Mn}$ (III), since the corresponding absorbance intensity was always the strongest one at $258 \mathrm{~nm}$. As the Mn(II) exposure time proceeded (> $8 \mathrm{~h}$ ), the absorbances of $\mathrm{Mn}(\mathrm{III})$-PP complexes at $258 \mathrm{~nm}$ unceasingly decreased, suggesting that the accumulated Mn(III) in cell suspensions was possibly oxidized to $\mathrm{Mn}(\mathrm{IV})$ oxides. It is worthy to note that at $4 \mathrm{~h}$ of $\mathrm{Mn}$ (II) exposure, the absorbance of $258 \mathrm{~nm}$ was far below that of $8 \mathrm{~h}$ of exposure, and was much closer to that of cells without Mn(II) exposure, indicating that $\mathrm{Mn}$ (III) accumulation by cells may start at as early as the 4th $\mathrm{h}$ and reach the plateau at the 8th $\mathrm{h}$ after the cells were exposed to $\mathrm{Mn}(\mathrm{II})$. Besides, it should be noted that cells without $\mathrm{Mn}(\mathrm{II})$ exposure had a background peak at $258 \mathrm{~nm}$, not really meaning the presence of $\mathrm{Mn}(\mathrm{III})$.

Hence, the optimum time for Mn(III) accumulation by LLDRA6 at $4 \mathrm{~h}$ of cell incubation and $8 \mathrm{~h}$ of $\mathrm{Mn}$ (II) exposure were determined as the time parameters for cell incubation and the long-term $\mathrm{Mn}(\mathrm{II})$ exposure (i.e. $a=4$ and $b=8$ in section 2.4 ) in subsequent transcriptome sequencing, respectively (Fig. S2). 


\subsection{Transcriptomic differences of strain LLDRA6 between the short- term and the long-term exposure of $\mathrm{Mn}$ (II)}

Prior to analysis of DEGs, RNA-seq data were validated by qRT-PCR. As shown in Fig. S3, for each selected gene, the $\log _{2^{-}}$ transformed mean values obtained from qRT-PCR showed the similar trends of transcriptional upregulation or downregulation to the $\log _{2}$-transformed fold changes from transcriptome data, suggesting the reliability of data from RNA-seq.

A total of 547 DEGs were identified between cells with short-term exposure ( $0.5 \mathrm{~h}$ ) of $\mathrm{Mn}$ (II) (Mn(II)-short group) and cells with long-term exposure (8 h) of $\mathrm{Mn}(\mathrm{II})$ (Mn(II)-long group) (Table S3), while 1,468 DEGs were identified between cells with shortterm incubation (CK-short group) and cells with long-term incubation (CK-long group) in the absence of Mn(II). Venn diagram analyses further showed that out of 547 DEGs, 300 were identified as unique ones between $\mathrm{Mn}$ (II)-short and Mn(II)-long groups, indicating that they were not caused by cell growth but only due to the exposure of Mn(II) (Fig. 2A). The other 247 DEGs were shared between control groups and Mn groups, suggesting that they were not only attributed to Mn(II) exposure but also attributed to cell growth.

In those 300 unique DEGs, 132 were upregulated and the other 168 were downregulated as shown in Table S4. To better understand their potential roles in Mn(II) oxidation after cells were exposed with Mn(II), KEGG pathway enrichment analyses were performed. The top 20 of KEGG pathways with the minimum P-value were shown as an enrichment bubble diagram (Fig. 2B). Notably, metabolism pathways related to aromatic or heterocyclic rings, such as phenylalanine metabolism (also known as phenylacetic acid metabolism), histidine metabolism, nitrotoluence metabolism, tyrosine metabolism, and ascorbate metabolism, were markedly enriched with Mn(II) exposure. Particularly, among them, phenylacetic acid metabolism aroused us a special attention, because its operon, consisted of fourteen-member phenylacetic acid genes (paa), was found to be the most transcriptionally upregulated in 547 DEGs between Mn(II)-short and Mn(II)-long groups (Table 1 and Table S3). 
Table 1

Transcriptional expression profiles of 14 paa genes involved in phenylacetic acid metabolism pathway.

\begin{tabular}{|llllllll|}
\hline Gene ID & Orthology & $\begin{array}{l}\text { CK- } \\
\text { shortmean } \\
\text { TPMa }\end{array}$ & $\begin{array}{l}\text { CK- } \\
\text { long_mean } \\
\text { TPM }\end{array}$ & $\begin{array}{l}\text { Mn(II)- } \\
\text { short_mean } \\
\text { TPM }\end{array}$ & $\begin{array}{l}\text { Mn(II)- } \\
\text { long_mean } \\
\text { TPM }\end{array}$ & $\begin{array}{l}\log _{2} \text { (CK- } \\
\text { long/CK- } \\
\text { short) }\end{array}$ & $\begin{array}{l}\text { log }_{2} \text { (Mn(II)- } \\
\text { long/Mn(II)- } \\
\text { short) }\end{array}$ \\
\hline ProLLDRA6GL000272 & paaY & 32.64 & 61.73 & 74.01 & 758.54 & 0.91 & 3.35 \\
\hline ProLLDRA6GL000273 & paaX & 23.87 & 44.59 & 77.72 & 1562.21 & 0.90 & 4.32 \\
\hline ProLLDRA6GL000285 & paaZ & 12.84 & 23.63 & 31.08 & 1191.03 & 0.87 & 5.26 \\
\hline ProLLDRA6GL000277 & paaH & 112.91 & 561.12 & 66.61 & 4415.75 & 2.31 & 6.06 \\
\hline ProLLDRA6GL000282 & paaC & 9.93 & 27.88 & 20.71 & 2183.88 & 1.48 & 6.71 \\
\hline ProLLDRA6GL000278 & paaG & 13.17 & 121.74 & 36.80 & 3933.31 & 3.20 & 6.73 \\
\hline ProLLDRA6GL000279 & paaF & 1.84 & 18.44 & 12.12 & 1456.28 & 3.32 & 6.91 \\
\hline ProLLDRA6GL000281 & paaD & 1.04 & 3.16 & 5.16 & 656.06 & 1.59 & 6.98 \\
\hline ProLLDRA6GL000283 & paaB & 1.55 & 5.76 & 2.78 & 469.19 & 1.89 & 7.40 \\
\hline ProLLDRA6GL000284 & paaA & 1.25 & 3.07 & 5.01 & 1076.80 & 1.29 & 7.74 \\
\hline ProLLDRA6GL000275 & paaJ & 8.35 & 24.33 & 23.64 & 5117.34 & 1.54 & 7.76 \\
\hline ProLLDRA6GL000274 & paaK & 7.43 & 21.36 & 29.78 & 7525.53 & 1.52 & 7.98 \\
\hline ProLLDRA6GL000276 & paal & 1.65 & 2.71 & 6.26 & 1671.92 & 0.71 & 8.05 \\
\hline ProLLDRA6GL000280 & paaE & 1.21 & 4.95 & 11.06 & 3051.35 & 2.03 & 8.10 \\
\hline a: TPM is the abbreviation for transcripts per kilobase million. & & & & \\
\hline
\end{tabular}

Additionally, according to characteristics of enzymes catalyzing for Mn(II) oxidation (including copper binding motifs and heme/Ca(II) binding domains) as reported in other bacterial species, we found only two putative MCOs-type proteins possibly responsible for Mn(II) oxidation in strain LLDRA6, i.e. CotA and laccase (Table S5), after cluster of orthologous groups of proteins annotation (COG) for the complete genome of LLDRA6 (Su et al. 2013; Schlosser and Höfer, 2002). However, as shown in Table S5, in comparison with the short-term Mn(II) exposure, the transcriptional expressions of $\operatorname{Cot} A$ genes were decreased after the long-term Mn(II) exposure. For laccase, there was no marked increase for transcriptional expression in response to the long-term $\mathrm{Mn}$ (II) exposure. So, under the current condition (50 mM of Mn(II) exposure), it cannot be determined that how much role have these MCOs-type enzymes played in the formation of Mn oxides via direct Mn(II) oxidation.

\subsection{Sharp activation of phenylacetic acid metabolism pathway may hint ROS variation in LLDRA6}

Previous studies have shown that in aerobic bacteria, the complex of enzymes encoded by the paa cluster is responsible for degradation of phenylacetic acid (PAA) and its derivatives (Teufel et al. 2010; Teufel et al. 2012; Cook, 2019). Intriguingly, after exhaustingly searching for relevant literatures, we find that phenylacetate catabolism is also important for resisting killing by $\mathrm{H}_{2} \mathrm{O}_{2}$ in bacteria (Green et al. 2020). A $\Delta$ paa mutant of Acinetobacter baumannii, which lacks part of the phenylacetate degradation pathway, was found to be more susceptible to $\mathrm{H}_{2} \mathrm{O}_{2}$ killing than a wild-type strain. The authors suggest that phenylacetate degradation may only be required to withstand environmental $\mathrm{H}_{2} \mathrm{O}_{2}$ encountered at high concentrations ( $\geq 40$ mM) (Green et al. 2020). Herein, we supposed that for strain LLDRA6, the drastically upregulated expression of the paa cluster might attach to the variation of ROS contents in cells, due to the stress of ambient Mn(II) ions. Therefore, we further qualitatively analyzed variation of ROS contents for strain LLDRA6 with and without the exposure of Mn(II). 


\subsection{ROS variation in LLDRA6 with and without Mn(II) exposure}

$2^{\prime}, 7^{\prime}$-Dichlorofluorescin diacetate (DCFDA), capable of freely penetrating the cell membrane into the cytoplasm, is commonly used as a fluorometric probe for qualitative detection of various ROS in cells (Fan and Li, 2014). Since LB media could produce a certain amount of ROS (as later evidenced by Fig. 4 and Fig. 5), they were removed by centrifugation before detection of ROS by DCFDA. As shown in Fig. 3, fluorescent characteristic peaks of ROS produced by cells occur at $526 \mathrm{~nm}$ in the range of $510-650 \mathrm{~nm}$. No matter which the $\mathrm{Mn}(\mathrm{II})$ exposure time was ( $0.5 \mathrm{or} 8 \mathrm{~h}$ ), the fluorescence intensities of cells with exposure of $50 \mathrm{mM} \mathrm{Mn(II)} \mathrm{were} \mathrm{stronger} \mathrm{than} \mathrm{that} \mathrm{of} \mathrm{cells} \mathrm{with} \mathrm{no} \mathrm{exposure} \mathrm{of} \mathrm{Mn}(\mathrm{II})$, at an equivalent level of cell density $\left(\mathrm{OD}_{600}\right.$ of 0.9 for the short-term exposure group, and $\mathrm{OD}_{600}$ of 1.7 for the long-term exposure group), suggesting a significant variation of ROS contents in strain LLDRA6 with and without the exposure of $\mathrm{Mn}(\mathrm{II})$.

\subsection{Evidence for $\mathrm{Mn}(\mathrm{II})$ oxidation by LLDRA6 via superoxide generation coupled to hydrogen peroxide consumption}

Commonly, ROS are short-lived oxygen radicals generated in the reduction of oxygen to water via the electron transfer chains, including $\left(\mathrm{O}_{2}^{-}\right), \mathrm{H}_{2} \mathrm{O}_{2},{ }^{1} \mathrm{O}_{2}, \mathrm{HO}_{2}^{-}, \mathrm{HO}^{-}, \mathrm{ROO}^{-}$, and $\mathrm{RO}^{-}$, etc. (Hansel et al. 2019; Fan and $\left.\mathrm{Li}_{1}, 2014\right)$. As described by the reaction 1 above, since $\left(\mathrm{O}_{2}^{-}\right)$and $\mathrm{H}_{2} \mathrm{O}_{2}$ play a key role in indirect oxidation of $\mathrm{Mn}(\mathrm{II})$, their contents in cells were specifically tested with and without $\mathrm{Mn}(\mathrm{II})$ exposure.

As shown in Fig. 4A, LB medium was able to generate a large amount of $\left(\mathrm{O}_{2}^{-}\right)_{\text {by itself, even producing 2-fold greater amount }}$ of $\left(\mathrm{O}_{2}^{-}\right)$in the presence of $50 \mathrm{mM}$ of $\mathrm{Mn}(\mathrm{II})$. So, LB medium was removed by centrifugation prior to detection of $\left(\mathrm{O}_{2}^{-}\right)$ produced by cells.

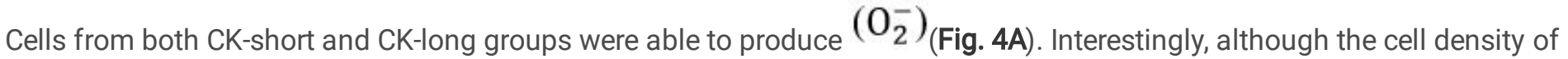
CK-long $\left(\mathrm{OD}_{600}=1.7\right)$ was nearly two times greater than that of $\mathrm{CK}$-short $\left(\mathrm{OD}_{600}=0.9\right)$, the $\left(\mathrm{O}_{2}^{-}\right)$concentration of cells from CKlong $(2.19 \mu \mathrm{M})$ was much lower than that of cells from CK-short $(5.26 \mu \mathrm{M})$. The similar trend of an inverse relationship between cell density and $\left(\mathrm{O}_{2}^{-}\right)$production, has also been observed in other bacteria (Diaz et al. 2013; Hansel et al. 2019). These studies show that $\left(\mathrm{O}_{2}^{-}\right)$concentrations steadily increased during active growth but then declined upon entering stationary phase, indicating their potential involvement in cell signaling except for simple responses to oxidative stress within microbial or environmental systems (Hansel et al. 2019).

When the cells were exposed to $50 \mathrm{mM}$ of $\mathrm{Mn}(\mathrm{II})$ for $0.5 \mathrm{~h},\left(\mathrm{O}_{2}^{-}\right)$concentration of cells from $\mathrm{Mn}(\mathrm{II})$-short (5.06 $\left.\mu \mathrm{M}\right)$ slightly declined, as compared to that of cells from CK-short $(5.26 \mu \mathrm{M})$, perhaps indicating a rapid involvement of $\left(\mathrm{O}_{2}^{-}\right)$in $\mathrm{Mn}(\mathrm{II})$ oxidation. As the $\mathrm{Mn}(\mathrm{II})$ exposure time increased to $8 \mathrm{~h},\left(\mathrm{O}_{2}^{-}\right)$concentration of cells from $\mathrm{Mn}(\mathrm{II})$-long significantly increased in comparison to that of cells from CK-long (from 2.19 to $2.88 \mu \mathrm{M}$ ), presumably because strain LLDRA6 was in middle of oxidizing $\mathrm{Mn}(\mathrm{II})$ ions when a vast amount of $\left(\mathrm{O}_{2}^{-}\right)$were needed to constantly produce, as evidenced by the fact that $8 \mathrm{~h}$ of Mn(II) exposure was the optimum time for cells to accumulate Mn(III) (Fig. 1).

However, it cannot be ignored that substances other than living cells (e.g. LB media, Mn(II) ions and dead cells), were also capable of producing $\left(\mathrm{O}_{2}^{-}\right)$during incubation (Fig. 4A). In order to confirm that $\left(\mathrm{O}_{2}^{-}\right)$only generated by living cells is the true oxidant for Mn(II) oxidation, Mn(III)-trapping and leucoberbelin blue (LBB) stain assays (Krumbein and Altmann, 1973) were tested for living cells, LB media, and dead cells. 
As shown in Fig. 4B, no absorption peak of Mn(III)-PP complexes could be found at $258 \mathrm{~nm}$ for LB medium in the absence and presence of $\mathrm{Mn}(\mathrm{II})$, showing that $\left(\mathrm{O}_{2}^{-}\right)$produced by the medium was ineffective in oxidizing $\mathrm{Mn}(\mathrm{II})$. Also, dead cells in LB medium with or without addition of $\mathrm{Mn}$ (II) were not capable of producing Mn(III)-PP complexes after $8 \mathrm{~h}$ of incubation, since no characteristic peaks were detected at $258 \mathrm{~nm}$. By comparison, living cells grown in LB medium with addition of Mn(II) produced a much stronger characteristic peak at $258 \mathrm{~nm}$ than living cells grown in the absence of $\mathrm{Mn}$ (II) did (considered as the background peak). Then, the strong characteristic peak produced by living cells grown in the presence of $\mathrm{Mn}(\mathrm{II})$, markedly attenuated as excessive superoxide dismutase (SOD) was used to scavenge superoxide. These results suggest that $\left(\mathrm{O}_{2}^{-}\right)$ only produced by living cells are involved in the formation of Mn(III)-PP complexes after $8 \mathrm{~h}$ of cell incubation. More importantly, after $4 \mathrm{~d}$ of continuous incubation, only the suspension of living cells incubated in LB medium with addition of Mn(II) showed deep blue in LBB stain assays (Fig. 4C), confirming the presence of Mn oxides. Thus, these results demonstrate that $\left(\mathrm{O}_{2}^{-}\right)$only generated by living cells is the true oxidant for $\mathrm{Mn}(\mathrm{II})$ oxidation.

It is generally accepted that the production of $\left(\mathrm{O}_{2}^{-}\right)$alone does not ensure the formation of Mn oxides in indirect $\mathrm{Mn}$ (II) oxidation, since $\mathrm{H}_{2} \mathrm{O}_{2}$ produced by cells may facilitate the reduction of $\mathrm{Mn}$ (III) to $\mathrm{Mn}$ (II) (Andeer et al. 2015; Lingappa et al. 2019). For instance, a marine alpha-protobacterium, Ruegeria sp. TM1040, does not generate Mn oxides despite its fast production rates of extracellular $\left(\mathrm{O}_{2}^{-}\right)$(Diaz et al. 2013; Learman and Hansel, 2014).

As shown in Fig. 5 , the concentration of $\mathrm{H}_{2} \mathrm{O}_{2}$ generated by cells after $0.5 \mathrm{~h}$ exposure of $\mathrm{Mn}$ (II) (Mn(II)-short) was much higher than that produced by cells from the control group (CK-short), perhaps owing to the rapid response to oxidative stress. As the exposure time increased to $8 \mathrm{~h}$, the $\mathrm{H}_{2} \mathrm{O}_{2}$ concentration of $\mathrm{Mn}$ (II)-long cells significantly lowered in comparison to that of cells with no exposure of $\mathrm{Mn}$ (II) (CK-long), confirming a heavy consumption of $\mathrm{H}_{2} \mathrm{O}_{2}$ (from 25.99 to $22.87 \mu \mathrm{M}$ ), which facilitated to pull the equilibrium of the reaction 1 towards accumulation of $\mathrm{Mn}(\mathrm{III})$. A possible explanation for the consumption of $\mathrm{H}_{2} \mathrm{O}_{2}$ in cells of $\mathrm{Mn}$ (II)-long group, could be that the gene encoding catalase was significantly upregulated in transcription by 1.08-fold after the long-term Mn(II) exposure, as shown in Table S6, thus resulting in acceleration for decomposition reaction of $\mathrm{H}_{2} \mathrm{O}_{2}$.

Overall, these results suggest that Providencia sp. LLDRA6 exploited the indirect $\mathrm{Mn}(\mathrm{II})$ oxidation strategy of $\left(\mathrm{O}_{2}^{-}\right)$production coupled to $\mathrm{H}_{2} \mathrm{O}_{2}$ consumption to form Mn oxides.

\subsection{Prediction of links between ROS and phenylacetic acid metabolism pathway}

Figure 6 presents a schematic diagram for the proposed process of Mn oxides generation by Providencia sp. LLDRA6. Regardless of the absence and presence of direct enzymatic oxidation in LLDRA6 (Table S5), the formation of extracellular Mn oxides by LLDRA6, as evidenced by our previous work (Li et al. 2020), now can be partially attributed to the attack of $\left(\mathrm{O}_{2}^{-}\right)$that externally attached to cell membranes to $\mathrm{Mn}$ (II) (Learman et al. 2011b; Learman and Hansel, 2014; Andeer et al. 2015).

Once strain LLDRA6 is exposed to $50 \mathrm{mM}$ of $\mathrm{Mn}(\mathrm{II})$, excessive Mn(II) will be harmful to the cell viability, as previously evidenced by $\mathrm{OD}_{600}$ ( $\mathrm{Li}$ et al. 2020), probably through facilitating a higher level generation of ROS due to heavy-metal induced oxidative stress (Fig. 3) (Todsapol et al. 2020; Niu et al. 2020). ROS are often produced as by-products during the reduction of oxygen to water in electron transport chains (Hansel et al. 2019). Thus, enzyme complexes for respiration anchored in cell membrane may produce a large amount of extracellular $\left(\mathrm{O}_{2}^{-}\right)$for reacting with $\mathrm{Mn}(\mathrm{II})$ to generate extracellular Mn oxides. In addition, some proteins, such as AHPs, malate dehydrogenase and xanthine dehydrogenase, are reported to take part in production of extracellular $\left(\mathrm{O}_{2}^{-}\right)$via transmembrane transport (Andeer et al. 2015). 
After the long-term exposure of $\mathrm{Mn}(\mathrm{II})$, the transcriptional level of the paa cluster is drastically upregulated (Table 1), indicating that PAA or PAA-like derivatives sharply accumulates and needs to be degraded as soon as possible, because from a healthy perspective, the excessive aromatic compounds are harmful to cell vitality (Teufel et al. 2010). So, the question arises, why does the paa cluster be transcriptionally activated in the long-term presence of $\mathrm{Mn}$ (II), or what the link might be between ROS and the activation of PAA catabolic pathway. According to the detailed information from catabolic pathway of PAA in aerobic bacteria as reported by Teufel et al. (2010), we find that the crucial process for degrading the inert aromatic ring of PAA, is the introduction of an oxygen atom into the aromatic ring catalyzed by the multicomponent enzyme PaaABCDE, and then the subsequent formation of a highly reactive oxygen-containing, seven-member heterocycle (named oxepin) catalyzed by PaaG

(Fig. 6). Further, the ring of the $\mathrm{C}-\mathrm{O}$ seven-member heterocycle is cleaved and opened at the oxygen site catalyzed by PaaZ.

Therefore, for inert, recalcitrant aromatic rings, the formation of highly reactive oxepins via epoxidation is an elaborate strategy for ring cleavage (Teufel et al. 2010). According to this conclusion, possible links between ROS and activation of phenylacetic acid catabolism could possibly be explained by three reasons as follows. (1) Commonly, the oxygen $\left(\mathrm{O}_{2}\right)$ is used for epoxidation of the aromatic ring of PAA catalyzed by PaaABCDE. During the long-term exposure of Mn(II), the excessive ROS constantly produced in cells might replace the oxygen to involve in epoxidation, thus speeding up the catabolic pathway of PAA. (2) In fact, PAA catabolic pathway is not restricted to phenylacetate (Teufel et al. 2010). Other PAA-like aromatic compounds (e.g., benzoate, phenylalanine and styrene) can also enter in the same pathway for their degradation (Teufel et al. 2010). Hence, these PAA-like aromatic compounds might also be attacked by ROS to form highly reactive oxepins, thus greatly increasing their concentrations. Though exhibiting high chemical activity, oxepins are poisonous to cells, which need to be immediately hydrolyzed (Teufel et al. 2010), thereby further activating the PAA catabolic pathway. (3) the excessive oxygen radicals constantly produced in cells might result in a variety of oxygen-containing heterocycles that are similar to oxepins (oxepin-like ones) by attacking non-aromatic compounds (e.g., aliphatic hydrocarbons) (Meng et al. 2018), which may in turn greatly upregulate the transcriptional expression of the paa cluster.

Taken together, PAA, PAA-like derivatives and oxepin-like oxygen-containing heterocycles, may all be crowded in this catabolic pathway (Teufel et al. 2012), as a result of the response to $\mathrm{Mn}$ (II)-induced oxidative stress, consequently accelerating the transcription of the paa cluster. As to why does the bacterium choose PAA catabolic pathway for detoxification, a possible explanation is that all intermediates in this pathway are combined with CoA, which can be recognized rapidly and bound through CoA-binding motives of the processing enzymes (Teufel et al. 2010). More importantly, the final products of PAA catabolic pathway, acetyl-CoA and succinyl-CoA, are able to enter in the tricarboxylic acid cycle (TCA) for safe energy conservation.

\section{Conclusions}

In this work, the mechanism of Mn(II) oxidation by a soil-borne bacterium Providencia sp. LLDRA6 under high Mn(II) concentration (50 mM) was explored. Results from transcriptome sequencing for LLDRA6 brought an important clue to unravel the ROS-dependent behavior of Mn oxides production by LLDRA6, i.e., the sharply transcriptional upregulation of genes for phenylacetic acid catabolism, which might suggest a significant variation of ROS in cells during Mn(II) exposure.

Chemical activity assays for ROS confirmed that LLDRA6 exploited the indirect Mn(II) oxidation strategy of $\left(\mathrm{O}_{2}^{-}\right)_{\text {production }}$ coupled to $\mathrm{H}_{2} \mathrm{O}_{2}$ consumption to form Mn oxides. During $\mathrm{Mn}(\mathrm{II})$ exposure, the excessive ROS, generated in response to oxidative stress caused by $\mathrm{Mn}(\mathrm{II})$, transcriptionally activated genes for phenylacetic acid catabolism presumably by increasing concentrations of highly reactive oxepins.

\section{Declarations}

Author Contributions D.L. conceived and designed the study. S.C. and D.L. retrieved the literature and drafted the manuscript. Z.D., J.C., J.L., X.R., Z. L., F.L. and J.H. participated in the study design and editing of the manuscript. All authors read and approved the final manuscript. 
Acknowledgements This research was supported by the National Natural Science Foundation of China (32171622,

51774129), the Natural Science Foundation of Hunan Province (2021JJ50003, 2021JJ50034, 2019JJ50143), the Scientific Research Projects of Hunan Education Department (18C0491, 20B187 and 20C0588).

Conflicts of Interest The authors declare no conflicts of interest.

Data Availability The genome sequence included in the study has been submitted to GenBank with the accession numbers CP067099. The clean reads of genome sequencing are deposited in the NCBI Sequence Read Archive under BioProject PRJNA724814. The RNA-seq data are deposited in the NCBI Sequence Read Archive under BioProject PRJNA690198.

\section{References}

1. Andeer PF, Learman DR, Mcllvin M, Dunn JA, Hansel CM (2015) Extracellular haem peroxidases mediate Mn(II) oxidation in a marine Roseobacter bacterium via superoxide production. Environ Microbiol 17:3925-3936

2. Anderson CR, Johnson HA, Caputo N, Davis RE, Torpey JW, Tebo BM (2009) Mn(II) oxidation is catalyzed by heme peroxidases in "Aurantimonas manganoxydans" strain SI85-9A1 and Erythrobacter sp. strain SD-21. Appl Environ Microbiol 75:4130-4138

3. Butterfield CN, Lee SW, Tebo BM (2016) The role of bacterial spores in metal cycling and their potential application in metal contaminant bioremediation. Microbiol Spectr 4:TBS-T0018

4. Butterfield CN, Soldatova AV, Lee SW, Spiro TG, Tebo BM (2013) $\mathrm{Mn}(I I, I I I)$ oxidation and $\mathrm{MnO}_{2}$ mineralization by an expressed bacterial multicopper oxidase. Proc Natl Acad Sci USA 110:11731-11735

5. Cook SD (2019) An historical review of phenylacetic acid. Plant Cell Physiol 60: 243-254

6. Corstjens PLAM, de Vrind JPM, Goosen T, de Vrind-de Jong EW (1997) Identification and molecular analysis of the Leptothrix discophora SS-1 mofA gene a gene putatively encoding a manganese-oxidizing protein with copper domains. Geomicrobiol J 14:91-108

7. Cui H, Liu X, Tan W, Feng X, Liu F, Ruan HD (2008) Influence of Mn(III) availability on the phase transformation from layered buserite to tunnel-structured todorokite. Clays Clay Miner 56:397-403

8. Diaz JM, Hansel CM, Voelker BM, Mendes CM, Andeer PF, Zhang T (2013) Widespread production of extracellular superoxide by heterotrophic bacteria. Science 340:1223-1226

9. Dick GJ, Torpey JW, Beveridge TJ, Tebo BM (2008a) Direct identification of a bacterial manganese(II) oxidase, the multicopper oxidase MnxG, from spores of several different marine Bacillus species. Appl Environ Microbiol 74:15271534

10. Dick GJ, Podell S, Johnson HA, Rivera-Espinoza Y, Bernier-Latmani R, McCarthy JK, Torpey JW, Clement BG, Gaasterland T, Tebo BM (2008b) Genomic insights into Mn(II) oxidation by the marine alphaproteobacterium Aurantimonas sp. strain Sl85-9A1. Appl Environ Microbiol 74:2646-2658

11. Dobin A, Davis CA, Schlesinger F, Drenkow J, Zaleski C, Jha S, Batut P, Chaisson M, Gingeras TR (2013) STAR: ultrafast universal RNA-seq aligner. Bioinformatics 29:15-21

12. Fan B, Carvalhais LC, Becker A, Fedoseyenko D, Wirén N von, Borriss R (2012) Transcriptomic profiling of Bacillus amyloliquefaciens FZB42 in response to maize root exudates. BMC Microbiol 12:116

13. Fan LM, Li JM (2014) Evaluation of methods of detecting cell reactive oxygen species production for drug screening and cell cycle studies. J Pharmacol Tox Met 70:40-47

14. Francis CA, Casciotti KL, Tebo BM (2002) Localization of Mn(II)-oxidizing activity and the putative multicopper oxidase, MnxG, to the exosporium of the marine Bacillus sp. strain SG-1. Arch Microbiol 178:450-456

15. Geszvain K, McCarthy JK, Tebo BM (2013) Elimination of manganese(II,III) oxidation in Pseudomonas putida GB-1 by a double knockout of two putative multicopper oxidase genes. Appl Environ Microbiol 79:357-366 
16. Geszvain K, Smesrud L, Tebo BM (2016) Identification of a third Mn(II) oxidase enzyme in Pseudomonas putida GB-1. Appl Environ Microbiol 82:3774-3782

17. Green ER, Juttukonda LJ, Skaar EP (2020) The manganese-responsive transcriptional regulator MumR protects Acinetobacter baumannii from oxidative stress. Infect Immun 88: e00762-19

18. Hansel CM, Diaz JM, Plummer S (2019) Tight regulation of extracellular superoxide points to its vital role in the physiology of the globally relevant Roseobacter clade. mBio 10:e02668-e02618

19. Henkel JV, Dellwig O, Pollehne F, Herlemann DPR, Leipe T, Schulz-Vogt HN (2019) A bacterial isolate from the black sea oxidizes sulfide with manganese(IV) oxide. Proc Natl Acad Sci USA 116:12153-12155

20. Hens T, Brugger J, Cumberland SA, Etschmann B, Frierdich AJ (2018) Recrystallization of manganite $(\mathrm{Y}-\mathrm{MnOOH})$ and implications for trace element cycling. Environ Sci Technol 52:1311-1319

21. Johnson HA. Tebo BM (2008) In vitro studies indicate a quinone is involved in bacterial Mn(II) oxidation. Arch Microbiol 189:59-69

22. Kataoka K, Komori H, Ueki Y, Konno Y, Kamitaka Y, Kurose S, Tsujimura S, Higuchi Y, Kano K, Seo D, Sakurai T (2007) Structure and function of the engineered multicopper oxidase CueO from Escherichia coli-deletion of the methionine-rich helical region covering the substrate-binding site. J Mol Biol 373:141-152

23. Krumbein WE, Altmann HJ (1973) New method for detection and enumeration of manganese oxidizing and reducing microorganisms. Helgoland Wiss Meer 25:347-356

24. Larsen El, Sly LI, McEwan AG (1999) Manganese(II) adsorption and oxidation by whole cells and a membrane fraction of Pedomicrobium sp. ACM 3067. Arch Microbiol 171:257-264

25. Learman DR, Hansel CM (2014) Comparative proteomics of Mn(II)-oxidizing and non-oxidizing Roseobacter clade bacteria reveal an operative manganese transport system but minimal $\mathrm{Mn}(\mathrm{II})$-induced expression of manganese oxidation and antioxidant enzymes. Environ Microbiol Rep 6:501-509

26. Learman DR, Wankel SD, Webb SM, Martinez N, Madden AS, Hansel CM (2011a) Coupled biotic-abiotic Mn(II) oxidation pathway mediates the formation and structural evolution of biogenic Mn oxides. Geochim Cosmochim Ac 75:6048-6063

27. Learman DR, Voelker BM, Vazquez-Rodriguez Al, Hansel CM (2011b) Formation of manganese oxides by bacterially generated superoxide. Nat Geosci 4:95-98

28. Li B, Dewey CN (2011) RSEM: accurate transcript quantification from RNA-Seq data with or without a reference genome. BMC Bioinformatics 12:323

29. Li D, Li R, Ding Z, Ruan X, Luo J, Chen J, Zheng J, Tang J (2020) Discovery of a novel native bacterium of Providencia sp. with high biosorption and oxidation ability of manganese for bioleaching of heavy metal contaminated soils. Chemosphere 241:125039

30. Lingappa UF, Monteverde DR, Magyar JS, Valentine JS, Fischer WW (2019) How manganese empowered life with dioxygen (and vice versa). Free Radic Biol Med 140:113-115

31. Livak KJ, Schmittgen TD (2001) Analysis of relative gene expression data using real-time quantitative PCR and the 2$\Delta \Delta$ CT Method. Methods 25:402-408

32. Medina M, Rizo A, Dinh D, Chau B, Omidvar M, Juarez A, Ngo J, Johnson HA (2018) MopA, the Mn oxidizing protein from Erythrobactersp. SD-21, requires heme and $\mathrm{NAD}^{+}$for $\mathrm{Mn}(\mathrm{II})$ oxidation. Front Microbiol 9:2671

33. Meng S, Tang GL, Pan HX (2018) Enzymatic formation of oxygen-containing heterocycles in natural products biosynthesis. ChemBioChem 19: 2002-2022

34. Morgan JJ (2005) Kinetics of reaction between $\mathrm{O}_{2}$ and $\mathrm{Mn}$ (II) species in aqueous solutions. Geochim Cosmochim Ac 69:35-48

35. Nakama K, Medina M, Lien A, Ruggieri J, Collins K, Johnson HA (2014) Heterologous expression and characterization of the manganeseoxidizing protein from Erythrobactersp. strain SD21. Appl Environ Microbiol 80:6837-6842 
36. Niu A, Bian WP, Feng SL, Pu SY, Wei XY, Yang YF, Song LY, Pei DS (2020) Role of manganese superoxide dismutase (MnSOD) against $\mathrm{Cr}(I I I)$-induced toxicity in bacteria. J Hazard Mater 403: 123604

37. Ranieri ML, Ivy RA, Mitchell WR, Call E, Masiello SN, Wiedmann M, Boor KJ (2012) Real-time PCR detection of Paenibacillus spp. in raw milk to predict shelf life performance of pasteurized fluid milk products. Appl Environ Microbiol 78:5855-5863

38. Ridge JP, Lin M, Larsen El, Fegan M, McEwan AG, Sly LI (2007) A multicopper oxidase is essential for manganese oxidation and laccase-like activity in Pedomicrobium sp. ACM 3067. Environ Microbiol 9:944-953

39. Robinson MD, McCarthy DJ, Smyth GK (2010) edgeR: a Bioconductor package for differential expression analysis of digital gene expression data. Bioinformatics 26:139-140

40. Schlosser D, Höfer C (2002) Laccase-catalyzed oxidation of $\mathrm{Mn}^{2+}$ in the presence of natural $\mathrm{Mn}^{3+}$ chelators as a novel source of extracellular $\mathrm{H}_{2} \mathrm{O}_{2}$ production and its impact on manganese peroxidase. Appl Environ Microbiol 68:3514-3521

41. Soldatova AV, Balakrishnan G, Oyerinde OF, Romano CA, Tebo BM, Spiro TG (2019) Biogenic and synthetic $\mathrm{MnO}_{2}$ nanoparticles: size and growth probed with absorption and raman spectroscopies and dynamic light scattering. Environ Sci Technol 53:4185-4197

42. Soldatova AV, Romano CA, Tao L, Stich TA, Casey WH, Britt RD, Tebo BM, Spiro TG (2017a) Mn(II) oxidation by the multicopper oxidase complex Mnx: A coordinated two-stage Mn(II)/(III) and Mn(III)/(IV) mechanism. J Am Chem Soc 139:11381-11391

43. Soldatova AV, Tao L, Romano CA, Stich TA, Casey WH, Britt RD, Tebo BM, Spiro TG (2017b) Mn(II) oxidation by the multicopper oxidases complex Mnx: A binuclear activation mechanism. J Am Chem Soc 139:11369-11380

44. Su J, Bao P, Bai T, Deng L, Wu H, Liu F, He J (2013) CotA, a multicopper oxidase from Bacillus pumilus WH4, exhibits manganese-oxidase activity. PLoS ONE 8:e60573

45. Tebo BM, Bargar JR, Clement BG, Dick GJ, Murray KJ, Parker D, Verity R, Webb SM (2004) Biogenic manganese oxides: properties and mechanisms of formation. Annu Rev Earth PI Sc 32:287-328

46. Teufel R, Friedrich T, Fuchs $G$ (2012) An oxygenase that forms and deoxygenates toxic epoxide. Nature 483: 359-362

47. Teufel R, Mascaraque V, Ismail W, Voss M, Perera J, Eisenreich W, Haehnel W, Fuchs G (2010) Bacterial phenylalanine and phenylacetate catabolic pathway revealed. Proc Natl Acad Sci USA 107: 14390-14395

48. Thi NT, Do-Gun K, Seok-Oh K (2018) Synergistic effects of biogenic manganese oxide and Mn(II)-oxidizing bacterium Pseudomonas putida strain MnB1 on the degradation of 17 a-ethinylestradiol. J Hazard Mater 344:350-359

49. Todsapol T, Supat J, Supinda T, Tossapol L, Prayad P, Maleeya K, Choowong A (2020) Vacuolar $\mathrm{H}^{+}$-ATPase is involved in preventing heavy metal-induced oxidative stress in Saccharomyces cerevisiae. Environ Microbiol 22:2403-2418

50. van Waasbergen LG, Hildebrand M, Tebo BM (1996) Identification and characterization of a gene cluster involved in manganese oxidation by spores of the marine Bacillus sp. strain SG-1. J Bacteriol 178:3517-3530

51. Zhang L, Wang Y, Liu D, Luo L, Wang Y, Ye C (2018) Identification and characterization of als genes involved in D-allose metabolism in lineage II strain of Listeria monocytogenes. Front Microbiol 9:621

\section{Figures}



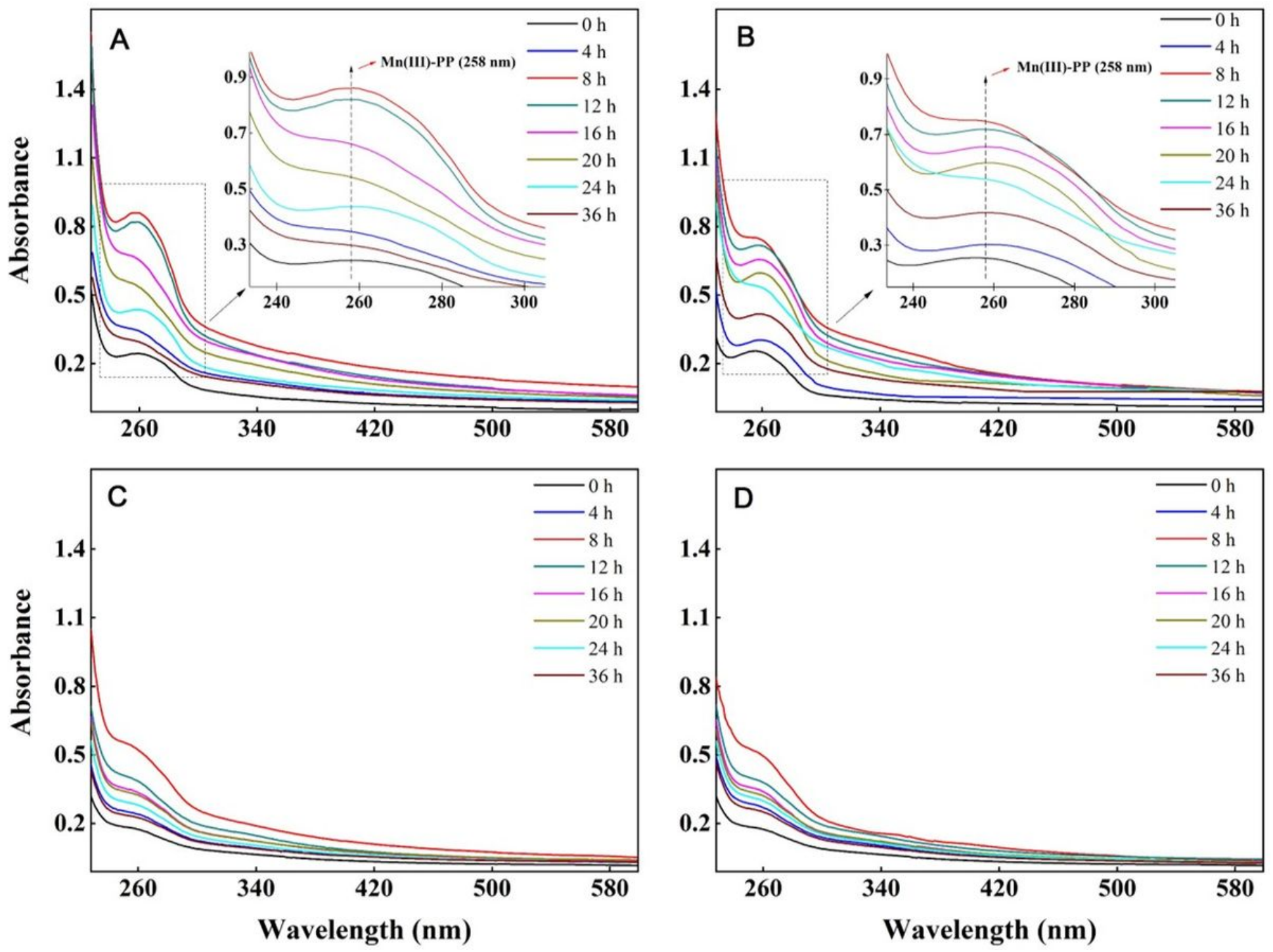

Figure 1

UV-vis adsorption spectra of bacterial suspensions consisted of Mn(II), PP and cells. After $4 \mathrm{~h}$ (A), $8 \mathrm{~h}$ (B), $12 \mathrm{~h}$ (C), and $24 \mathrm{~h}$ (D) of cell incubation, respectively, $0.5 \mathrm{mM}$ of $\mathrm{Mn}$ (II) and $0.5 \mathrm{mM}$ of PP were simultaneously added in cell suspensions, with cells being constantly incubated for different times ranging from 0 to $36 \mathrm{~h}$. Before detection of Mn(III)-PP complexes by UV, the cell suspension was diluted by 50 -fold with ddH2O. 

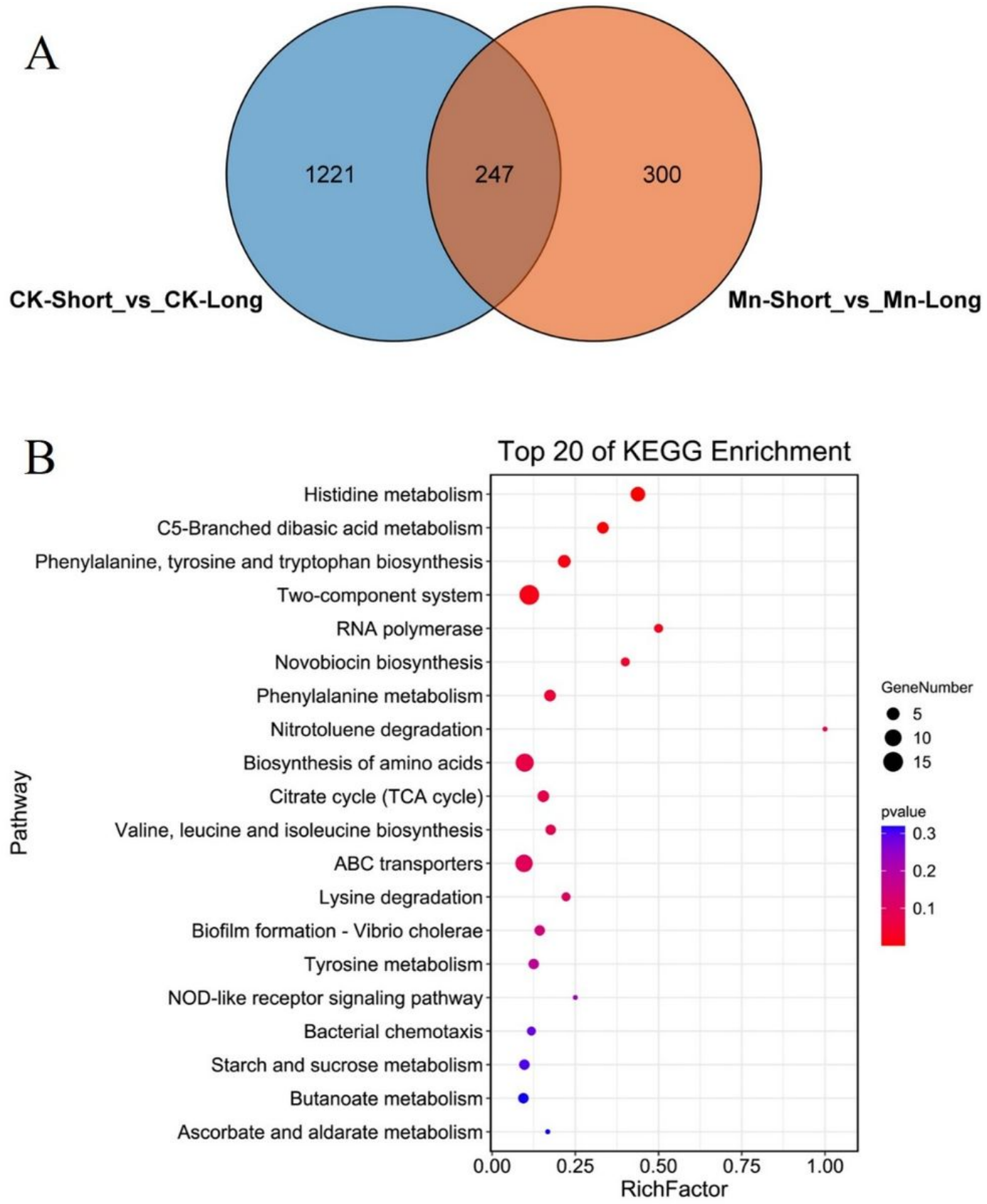

Figure 2

(A) Venn diagrams of DEGs between cells with short-term exposure of $\mathrm{Mn}$ (II) ( $\mathrm{Mn}$ (II)-short) and cells with long-term exposure of $\mathrm{Mn}$ (II) (Mn(II)-long), and DEGs between cells with short-term incubation (CK-short) and cells with long-term incubation (CKlong) in the absence of $\mathrm{Mn}$ (II). (B) KEGG enrichment analyses of those unique $300 \mathrm{DEGs}$ after Mn(II) exposure. The scatterplot illustrates the DEGs enriched in different functional pathways. The P-values on the right of the figure are the enrichment factors of DEGs. The size of dots denotes the number of DEGs. 


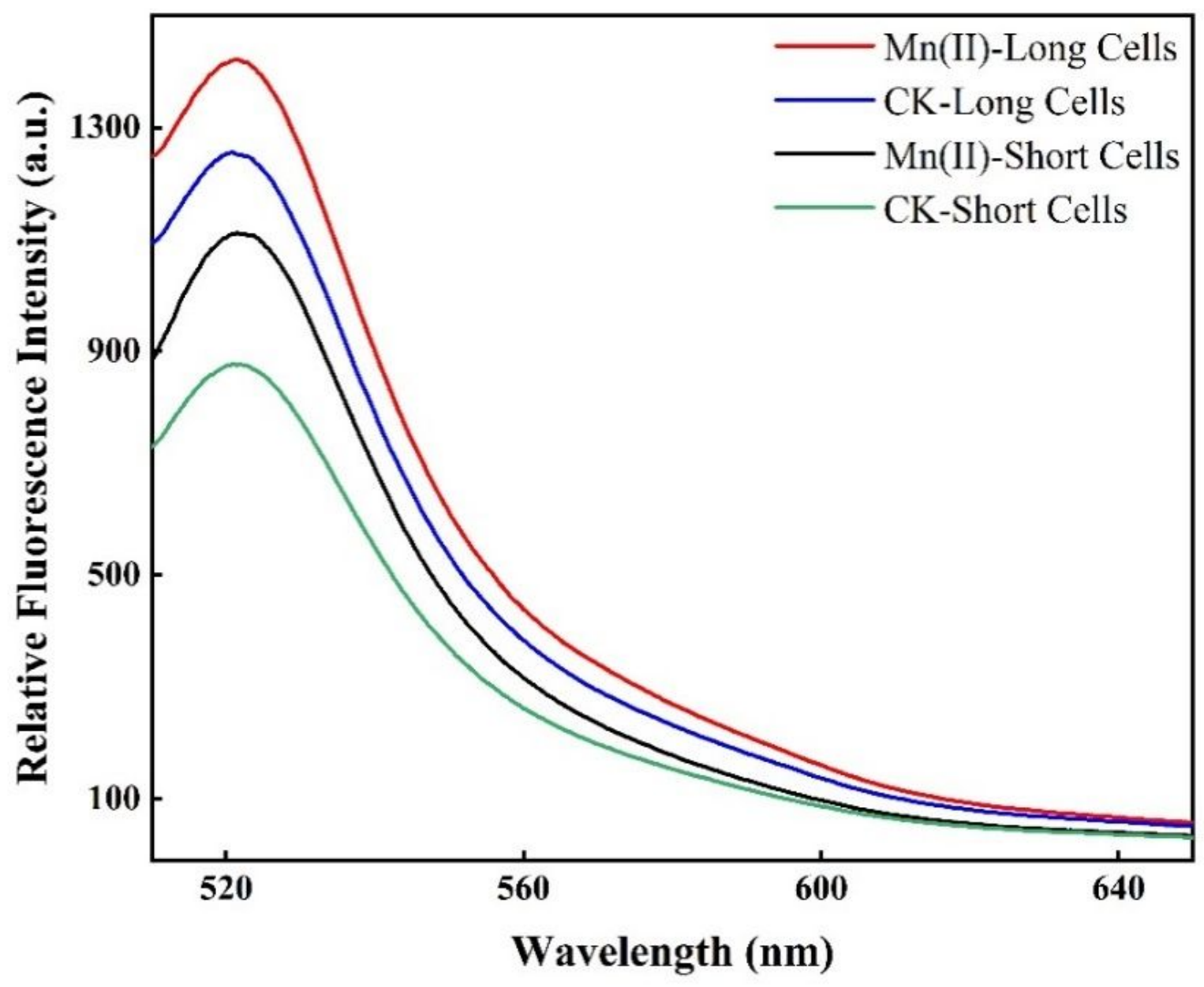

Figure 3

ROS fluorescence intensities of cells with exposure of $50 \mathrm{mM} \mathrm{Mn}$ (II) for $0.5 \mathrm{~h}$ (Mn(II)-short), cells with exposure of $50 \mathrm{mM}$ $\mathrm{Mn}$ (II) for $8 \mathrm{~h}$ (Mn(II)-long), cells without Mn(II) exposure for $0.5 \mathrm{~h}$ (CK-short), and cells without Mn(II) exposure for $8 \mathrm{~h}$ (CKlong), respectively, in the range of $510-650 \mathrm{~nm}$. 

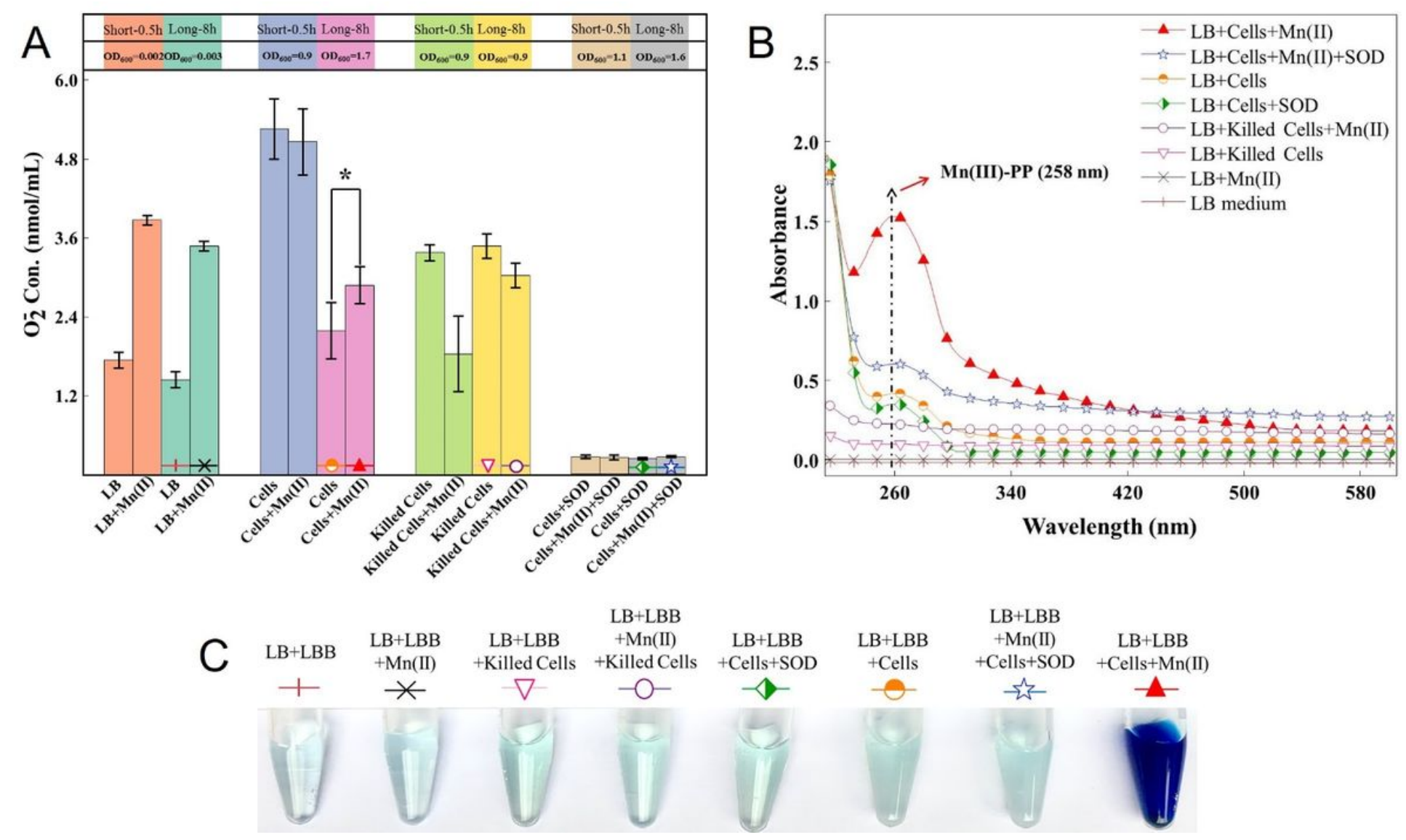

\section{Figure 4}

(A) Superoxide production by Providencia sp. LLDRA6. Cells from the four groups of CK-short, Mn(II)-short, CK-long, and Mn(II)-long were collected respectively by centrifugation for detection of superoxide. Meanwhile, LB liquid medium, dead cells, and living cells incubated with SOD were tested for superoxide production as controls. For detection of superoxide generated by the liquid medium, LB with no inoculation of LLDRA6 was cultured in the same manner as done for groups of Mn(II)-short, $\mathrm{Mn}$ (II)-long, CK-short, and CK-long, respectively. For detection of superoxide produced by dead cells, LLDRA6 was firstly incubated for $4 \mathrm{~h}$ in LB liquid medium, and then the total cell suspension was autoclaved at $121^{\circ} \mathrm{C}$ in 20 mins. Subsequently, all killed cells were collected by centrifugation and transferred in a fresh LB liquid medium with or without addition of $50 \mathrm{mM}$ of $\mathrm{Mn}$ (II) for further incubation of $0.5 \mathrm{~h}$ or $8 \mathrm{~h}$, respectively. Then, the dead cells were collected by centrifugation for detection of superoxide. For removal of superoxide, SOD (S2515, Sigma) was added in cell suspensions of Mn(II)-short, Mn(II)-long, CKshort, and CK-long, respectively, with a final concentration of $500 \mathrm{U} / \mathrm{mL}$. Then, the cells were collected by centrifugation for detection of superoxide. Asterisk ( ${ }^{*}$ ) denotes the significant difference at $\mathrm{P}<0.05$ level using independent samples t-test. (B) Trapping of $\mathrm{Mn}$ (III)-intermediate by the ligand PP. Experimental treatments marked with specific symbols as shown in (A) were repeated, only except for addition of $0.5 \mathrm{mM}$ of $\mathrm{Mn}$ (II) instead of $50 \mathrm{mM}$ of $\mathrm{Mn}$ (II) for $\mathrm{Mn}$ (II) exposure. This is because the volume of cell suspension would nearly increase by $20 \%$ if the final concentration of $50 \mathrm{mM}$ of PP were used (according to the manufacturer's instructions, the greatest concentration of stocking solution for PP is approximately $285.5 \mathrm{mM}$ ), thus resulting in a significant alteration in LB formula during cell incubation. The equal amounts of $\mathrm{Mn}$ (II) and PP (0.5 mM) were simultaneously added into the cell suspension for $8 \mathrm{~h}$ of incubation. After that, the cell suspension was diluted by 50 -fold with ddH2O for detection of Mn(III)-PP complexes by UV. (C) LBB stain assays. Cell suspensions marked with specific symbols from (A) were continued to incubate for $4 \mathrm{~d}$, and then mixed with $0.04 \%$ LBB (Vcell: VLBB $=1: 5)$ for staining. 


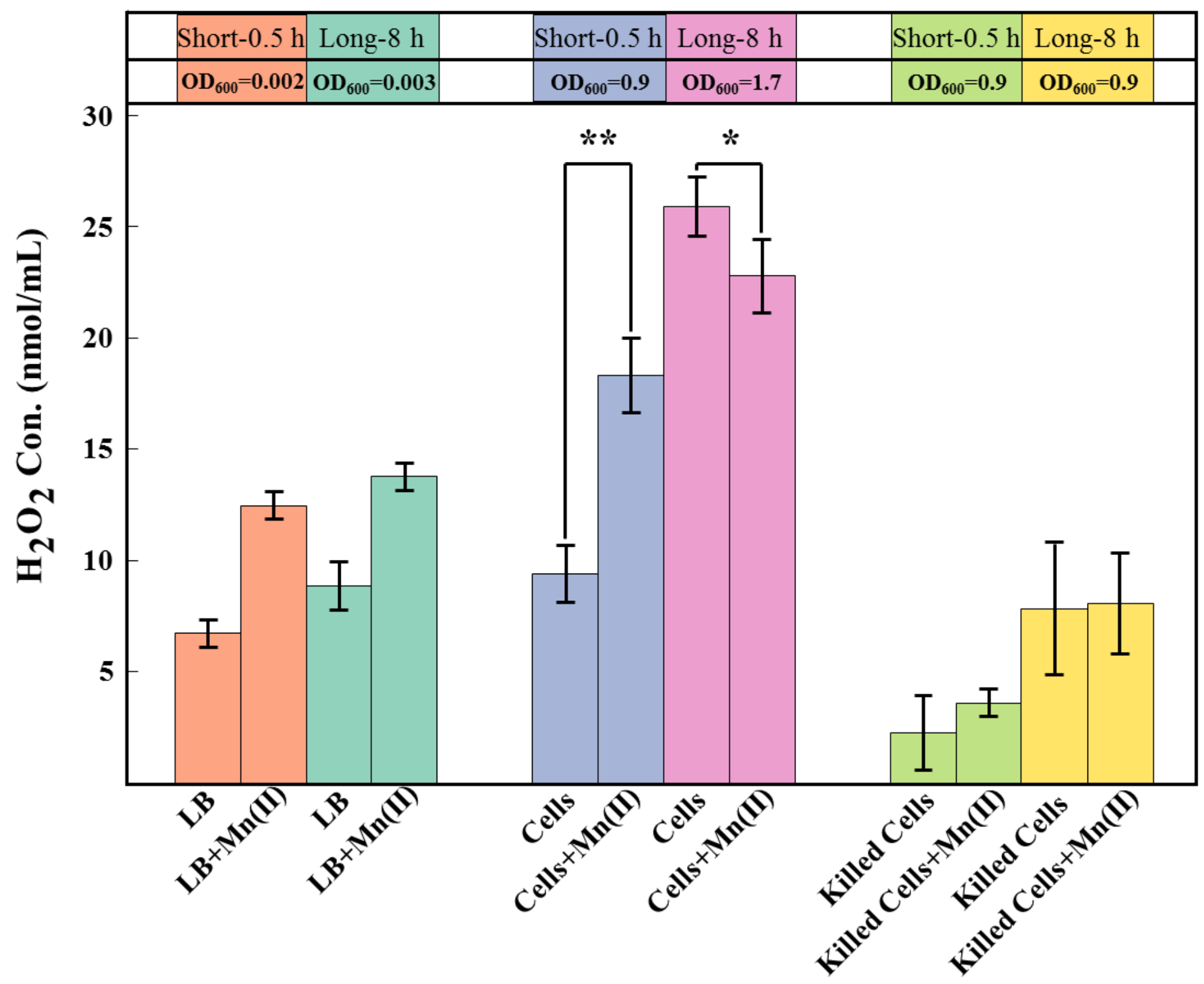

Figure 5

$\mathrm{H} 2 \mathrm{O} 2$ concentrations of living cells from groups of CK-short, Mn(II)-short, CK-long, and Mn(II)-long, respectively. Additionally, LB media with or without addition of $50 \mathrm{mM} \mathrm{Mn}(\mathrm{II})$, and dead cells incubated in LB media with or without addition of $50 \mathrm{mM}$ $\mathrm{Mn}$ (II) were used as controls. * and ** represent the significant difference within each test group at $\mathrm{P}<0.05$ and $\mathrm{P}<0.01$ levels using independent samples t-test, respectively. 


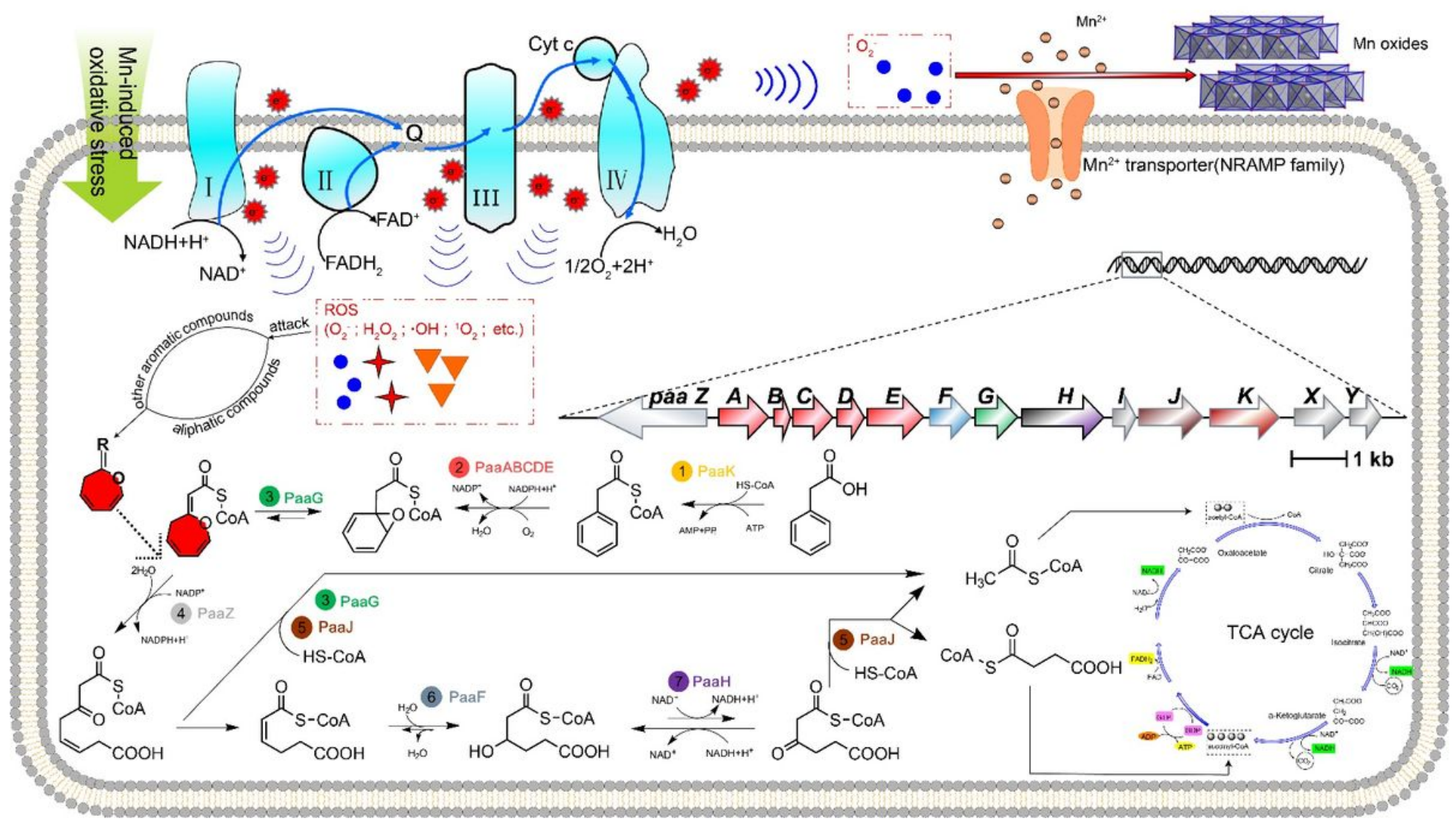

Figure 6

A proposed schematic diagram for processes of Mn oxides formation by Providencia sp. LLDRA6. Phenylacetic acid catabolic pathway was quoted from Teufel et al. (2010).

\section{Supplementary Files}

This is a list of supplementary files associated with this preprint. Click to download.

- Supplementarymaterial.docx

- TableS3.xlsx

- TableS4.xIsx 